\title{
1. Introduction: the political entrepreneur for regional growth and entrepreneurial diversity
}

\section{Daniel Silander and Charlotte Silander}

Using social science and economics perspectives, the goal of this study is to complement the dominant business administration research on entrepreneurship by increasing our knowledge of the economic-political context in which entrepreneurship and private enterprise are conducted. This book explores the role of political entrepreneurs for regional growth and entrepreneurial diversity in Sweden. We define a political entrepreneur as a politician/bureaucrat/officer/department within the publicly funded sector who with innovative approaches encourages entrepreneurship/business and where the goals are growth, employment and the common good. The approach of this book is to enrich the established research on entrepreneurship with in-depth knowledge of the conditions for entrepreneurship in Sweden. The main focus of study is the role the political entrepreneur might play in promoting entrepreneurship, enterprise and entrepreneurial diversity in the Swedish economy.

This study problematizes political entrepreneurship by analysing the circumstances under which political entrepreneurs operate, and by examining the interaction between political entrepreneurs and private sector entrepreneurs. It is assumed that the political entrepreneur and political entrepreneurship can influence the conditions for entrepreneurship and businesses, but previous research on entrepreneurs and entrepreneurship has to a large extent failed to recognize this political dimension. Research on the political entrepreneur in Sweden is limited, despite the fact that Swedish public debate has often expressed expectations of the political entrepreneur to promote regional growth, employment and welfare. It is also despite the fact that Swedish governments have promoted a vision of entrepreneurial diversity that sees a heterogeneous group of citizens as being entrepreneurial, integrated and equal in Swedish society. Nevertheless, this study on the political entrepreneur and political entrepreneurship 
is not restricted to an outcome-related definition. It is not just necessary that the political entrepreneur creates growth, employment and welfare, but by challenging existing norms and values in Swedish society, they should also seek to promote entrepreneurship in a new, innovative way that favours entrepreneurship and entrepreneurial diversity.

The aim of the study is two-fold: (1) to explore how political entrepreneurs may act to promote formal and informal institutions favourable to regional growth and welfare and (2) to investigate how political entrepreneurs may act to promote entrepreneurial diversity that promotes entrepreneurship and private enterprise among traditionally less entrepreneurial societal groups in Sweden. The study can be seen in relation to the research areas of entrepreneurship for growth and employment and entrepreneurship for social equality and integration. Overall, Swedish economy and social welfare would benefit from improved entrepreneurship and entrepreneurial diversity. Political entrepreneurs have the potential to be innovative and to promote entrepreneurship and entrepreneurial diversity by fundamentally challenging the prevailing formal and informal institutions for entrepreneurship in Swedish society. This is an important area of inquiry, particularly in times of economic recession and structural change for states and rural areas, when political leadership is crucial for private sector entrepreneurship, growth and welfare and when entrepreneurial ambitions, to lower the unemployment rate, are mostly welcomed from all societal groups and especially from those that have been less focused on by political entrepreneurs. The authors expect the analysis and discussions to be of great interest to politicians, public servants and political entrepreneurs in the public sector as well as entrepreneurs, business owners and investors in the economic sector, in addition to students of political science and economics.

An essential part of this study focuses on political entrepreneurship and regional growth, but another part is devoted to political entrepreneurship and entrepreneurial diversity with a focus on women, immigrants and young educated adults in Sweden. Throughout the study, the main focus is on how the complex networks of politicians and civil servants have a coordinating role to play, one that encourages cooperation, goal formulation and creative networking aimed at promoting entrepreneurship, private enterprise and regional growth.

There are three thematic areas covered throughout the book: 'Part I: Political entrepreneurship and entrepreneurship'; 'Part II: Political entrepreneurship and regional growth'; and 'Part III: Political entrepreneurship and entrepreneurial diversity'. Part I introduces a discussion on the political entrepreneur and political entrepreneurship. It is argued that, in times of economic stress, political entrepreneurship is essential to finding 
new ways of promoting growth, employment and welfare. The political entrepreneur is discussed from an actor-oriented perspective, focusing on how to promote favourable political, judicial and/or financial conditions by challenging traditional norms, values and regulations for entrepreneurship. This part of the book concludes with a discussion on the rule of law and the democratic boundaries to political entrepreneurs and political entrepreneurship. The political entrepreneur and political entrepreneurship are discussed in terms of legitimate and legal boundaries. To be a political entrepreneur is about challenging traditional patterns of behaviour to find new grounds for innovative methods to promote entrepreneurship. However, pushing for new norms and values in entrepreneurial policies may at times teeter on the edge of illegitimacy or even illegal activities. It is of great importance for the political entrepreneur to act within the legal and legitimate framework of entrepreneurial policies, while seeking new grounds for innovative ideas and methods to promote entrepreneurship.

Part II of the book discusses how the political entrepreneur and political entrepreneurship may provide for favourable institutional structures and policies for entrepreneurship and regional growth in Sweden. This may include pushing for entrepreneurial development among established entrepreneurs and businesses and/or to attracting individuals and companies with entrepreneurial aspirations to the region. It is argued that how formal and informal institutions are developed will have an impact on the entrepreneurial possibilities and problems in the region. Research on how to promote regional growth and welfare has, however, been overwhelmingly theoretical in nature. There are multiple models and theories on how policies could be developed and implemented and how the institutional framework for entrepreneurship should look, but there is a scarcity of empirical studies on how such models and theories may actually say something on regional entrepreneurship, business enterprises, growth and welfare. The remaining questions are, therefore, what types of interventions are needed to support entrepreneurship and business and what should the political entrepreneur actually do to develop a dynamic, successful policy for regional entrepreneurship and growth? The goal is to increase our understanding of what tools the political entrepreneur uses to promote favourable political entrepreneurship for a successful business policy. What are the policies to be developed and the institutional frameworks to be established to promote entrepreneurship and business that result in regional growth and welfare in the Swedish economy? It is obvious that there is a great need for both economic and political science research into how political entrepreneurs should primarily seek to actively work for a functioning business policy and how such 
empirical studies should be designed in collaboration between economists and political scientists.

Part III focuses on the role of political entrepreneurs and political entrepreneurship to promote entrepreneurial diversity. In its efforts to increase economic growth and employment, the Swedish government has been interested in widening entrepreneurship to different social groups. While business and entrepreneurship have traditionally been viewed as a male phenomenon, Swedish politicians have often emphasized how the Swedish economy needs all groups of society to be part of approaching the economic recession with new innovations and businesses and so on. The Swedish government has associated future economic growth with entrepreneurial diversity, but also with social equality and integration. When Swedish officials have spoken out on entrepreneurial diversity as a way of pushing for gender equality and growth, improved diversity has also been stressed as a tool for growth and integration of immigrants and young adults. It has been shown that women, immigrants and young adults are positioned outside the white, middle-aged male norm of entrepreneurship in Swedish society. Despite decades of Swedish political discussions on the importance of entrepreneurial diversity, women, immigrant and young adults are still less established in important social networks for political and economic entrepreneurship. The presence of homosocial networks therefore risks disadvantaging their participation and influence, with negative results for economic growth, employment and welfare.

This book concludes in Part IV by summarizing the study on political entrepreneurship for regional growth and entrepreneurial diversity. This concluding chapter sheds light on who the political entrepreneur may be and what formal and informal institutions may be challenged and changed by political entrepreneurs to favour entrepreneurship and businesses. The political entrepreneur is particularly important in times where normal work routines and everyday work do not necessarily solve societal challenges. Sometimes society faces major challenges, not necessarily a global economic crisis, that require extraordinary means to secure economic and social development. In times of profound economic crisis it is particularly important to have political entrepreneurs who dare to challenge traditional norms and values about promoting entrepreneurship by trying to introduce new ideas that later can become the prevailing norms and values for dynamic entrepreneurship. The study of political entrepreneurs is thus to examine the alternative methods that politicians, bureaucrats, officials and institutions may use to create better conditions for entrepreneurship and entrepreneurial diversity. 